\title{
Locarno 2002
}

\author{
By Gönül Dönmez-Colin
}

Fall 2002 Issue of KINEMA

\section{LOCARNO INTERNATIONAL FILM FESTIVAL 2002}

Locarno(1-11 August, 2002) celebrated its $55^{\text {th }}$ anniversary with a selection of films that favoured Europe. The festival, which is somewhat squeezed between Cannes and Venice, seemed to have chosen this year a general policy of showcasing interesting and enjoyable films to its summertime public, rather than engaging in a futile chase of undiscovered talent.

Twenty-two films competed for the Golden and Silver Leopards. Two very stimulating films of this section, which incidentally escaped the jury, were the latest work of Gus Van Sant (Drugstore Cowboy, Good Will Hunting, Finding Forester), a visual, contemplative voyage interior called Gerry and Rebecca Miller's Personal Velocity, a 'woman's film' to say the least.

The story of Gerry, if there is one, involves two young men, both of whom are named Gerry, who go for a walk and get lost. First it seems like a bad joke, but then the reality slowly sinks in. The characters are manipulated almost like puppets on a string by the constantly changing and at the same time very static landscape, which is often reminiscent of the arid landscapes in the photography of Abbas Kiarostami. In philosophical terms, the smallness of mankind and the absurdity of all little quibbles in the enormity and omnipotence of nature is a fearful message, but Van Sant is adept at distancing and even bringing moments of comic relief to such a serious subject.

The second film, Personal Velocity is more down to earth in dealing with human issues. Based on Miller's (who happens to be Arthur Miller's daughter) own collection of stories, the three episodes involve three female protagonists who are somewhat scarred by their past and their relationship with their father. The time span covered in the film is the period when they decide to take destiny in their own hands. Miller tries to connect these stories through a chance event that each protagonist encounters or experiences and this is the weak point of the film as the way she goes around the task is somewhat artificial. The film was shot in digital, which gives a feeling of intimacy that all players convey with a natural style.

A film rather representative of the new 'new wave' of Iranian cinema with its focus on modern Iranian women, was Man, Taraneh, Panzdah Sal Daram (I'm Taraneh, Fifteen). Director Rassul Sadr-Ameli made several films before reaching Western audiences in 1999 with The Girl in Sneakers about a run-away teenager.

The protagonist of his new film is a girl with a head on her shoulders except that she is soon to become an unwed mother and contrary to the impositions of society, she plans to raise her baby on her own. Believable? Hard to say no with such a convincing performance by newcomer Tareneh Allidousti.

Xiang Ji Mao Yi Yang Fei (Chicken Poets) by a 35-year-old Beijing theatre director, Meng Jing Hui bets poetry against chicken farming in this absurd story about absurd times. There are black hens, a colour blind girl who dreams of leaving her black and white village, a pirated CD with magical powers to bring fame and fortune overnight to an unpublished poet without inspiration and finally, the million dollar question about the place of the artist in our consumer society.

Iain Dilthey's Das Verlangen (The Longing), a graduation film, which completes the trilogy he calls Sehnsuchtstrilogie is about solitude and the feeling of abandonment. Contrary to the first two films where the protagonists search for the family of their dreams, here the family is under interrogation. According to Dilthey, "..the family constitutes the last true battle-ground of our time. Nowhere else are humans as vulnerable, fragile and naked as within this microcosm."

From France, La cage (The Cage) by Alain Raoust is a film about starting over without the melodrama that often accompanies the theme. A young woman who was convicted of armed robbery is released from prison for good behaviour. She has to start a new life, but before doing so she has to put some meaning into events as she is still too young to have digested all. The film is a discreet and subtle unrevealing of the long and 
difficult process the protagonist has to go through to free herself. The unassuming, unpretentious acting, the reflective camerawork, all add to the mood in this first feature film of remarkable merit.

Szep Napok (Pleasant Days) by Hungarian Kornel Mundruczo is the continuation of the theme of the world of petty criminals who vent their frustrations through mindless violence and loveless sex, which Mundruczo has been exploring for some time. The main character is actually someone from a detention centre and more or less plays himself. The documentary feeling is augmented by the use of other amateurs as well and plenty of improvisation.

Tan de repente (Suddenly) by Diego Lerman from Argentina is a film about relationships in a constantly changing world. The restless wonderings of the young souls is very much $\tilde{A}$ la early Wenders or Jarmusch, but some elements of the narration are definitely Latin American.

The video competition, which included twenty films (also 9 by Ãœmit Ãœnal mentioned in the Istanbul review) was explorative and innovative in general, a South Korean portmanteau film receiving worthwhile attention. Jeon jang keu $i$ hu (After the War) consisted of three digital short films made by three filmmakers from countries that were victims of World War II. Japanese filmmaker Suwa Nobuhiro shot his piece with the Korean actress Kim Ho-jung and based it on a letter received from the American director Robert Kramer, whose father, an army doctor, found himself changed forever after returning from Hiroshima.

Korean Moon Seong-Wook, in Survival Games looked at another type of war raged by a stockbroker. Chinese Wang Xiaoshuai examined the unforeseen side of September 11 through the story of a woman in exile who is not able to visit her seriously ill father in China because of the delays in issuing a 'green card.'

Piazza Grande screenings are the biggest attraction in Locarno. Endowed with a giant screen (26 metres by 14) with a capacity of 7000 in a climate where nightly rain is the rule rather than exception, it is a testimony to what film lovers won't do for cinema. The impressive program this year included several soon-to-be cultfilms such as Ali G Indahouse by Mark Mylod (UK) and My Little Eye by Marc Evans (UK). Also screened were Novo, the slick post-modern piece by Jean-Pierre Limosin (Tokyo Eyes) about a man who can make love to his girlfriend each time like the first time since he can retain no memory, the latest film of Russian Pavel Lounguine, Tycoon and They Shoot the Horses, Don't They by Syndey Pollack who received the Life Time Achievement award of the festival.

While Filmmakers of Today offered a selection of films that dealt with current issues such as Ruzegar-e Ma (Our Times) about the presidential elections by Rakhshan Bani-Etemad from Iran, Leopards of Tomorrow, which usually gives space to short films by new talents, has opened a new section this year to explore the less known cinemas of Australia and New Zealand.

Sidebars of the Locarno are many and varied, but this year a rich panorama of Indian cinema, under the banner of Indian Summer and with an impressive book to accompany, was a feast in its own right from the most popular film of all time, Sholey by Ramesh Sippy to the latest opus by octogenarian Mrinal Sen who broke a silence of nine years with Aamaar Bhuvan (This, My Land). Story of ill-fated lovers who are manoeuvred to divorce and marry someone else, the film of Sen, which connects episodes through feelings rather than plot line, is strong on human values in a world where materialistic gains are the most coveted virtue.

\section{References}

\section{AWARDS}

Golden Leopard - First Best Film

Das Verlangen by Iain Dilthey (Germany)

Silver Leopard - Second Best Film

Tan de repente by Diego Lerman (Argentina)

Jury Special Prize

Man, Taraneh, Panzdah Sal Daram by Rassul Sadr-Ameli (Iran) 


\section{Best actress}

Tareneh Allidousti (in Man, Taraneh, Panzdah Sal Daram)

Best Actor

Giorgos Karayannis (in Diskoli Apocheretismi: O Babas Mou (Hard Goodbyes) by Penny Panayotopoulou Greece)

Silver Leopard for Debut Film

Szep Napok by Kornel Mundruczo (Hungary)

Best Video

Jeon Jang Keu I Hu by Suwa Nobuhiro (Japan), Mon Seong-Wook (Korea) and Wang Xiaoshuar (China) and Love and Diane by Jennifer Dworkin (US)

Leopards of Tomorrow: New Swiss Talent

Golden Leopard - Nuit de noces by Olga Baillif

Silver Leopard - Swapped by Pierre Monnad

Best Swiss Newcomer - Dust by Ruxanra Zenida

Australia and New Zealand Film Category

Golden Leopard - Delivery Day by Jane Mannig

Silver Leopard - Lost by Jo Kennedy

Leopards of Tomorrow (shared)

Swiss - Petits Gestes by Francois Rossier

Australian - The French Doors by Steve Ayson

FIPRESCI and Ecumenical Jury Prize

La cage by Alain Raoust (France)

NETPAC (Promotion of Asian Cinema)

$M r$ and Mrs Iyer by Aparna Sen (India)

Obor Kalandia by Sobi al-Zobaidi (Palestine)

Ruzegar-e ma (Our Times) by Rakhshan Bani-Etemad (Iran)

Critics' Week

Forget Baghdad-Jews and Arabs-The Iraqi Connection by Samir (Swiss/Germany)

Public Prize for a film shown on the Grande Piazza

Bend it like Beckham by Gurinder Chadha (UK)

\section{Author Information}

Gönül DÖNMEZ-COLIN is an independent researcher and writer whose publications include Women, Islam and Cinema, Cinemas of the Other: A personal Journey with Filmmakers from the Middle East and Central Asia, Cinema of North Africa and the Middle East (ed.); Turkish Cinema: Identity, Distance and Belonging (Reaktion Books), and Routledge Dictionary of Turkish Cinema (2014). 